\title{
Exchange Traded Funds Vs Index Funds: Comparative Performance Analysis
}

\author{
Effulgence \\ Vol. 16 (Special Issue) \\ January - June, 2018 \\ Rukmini Devi Institute of Advanced Studies \\ E-mail: effulgence@rdias.ac.in, Website: www.rdias.ac.in \\ $\mathrm{http}: / /$ effulgence.rdias.ac.in/user/default.aspx \\ https://dx.doi.org/10.33601/effulgence.rdias/v16/iSpl1/2018/article0.7
}

M s. A shima Gaba, Research Scholar, D ept. of Commerce and Business Studies, Jamia M illia Islamia - a Central University, New Delhi, E-mail-ashimagaba27@gmail.com

Dr. Ravinder K umar, Professor of Finance, Dept. of Commerce and Business Studies, Jamia M illia Islamia - a Central University, New Delhi, E-mail-rkumar4@jmi.ac.in

\begin{abstract}
Exchange Traded Funds (ETFs) and Index Funds both are innovative products. ETF s are baskets of securities that are traded on the stock exchange. It is a hybrid financial product that bears the twin features of a stock and a mutual fund whereas Index Funds are mutual funds which replicate the performance of broad market index but can be purchased or redeemed only at the end of the day at the value of their net assets (NAV). The proposed study aims to cover the performance evaluation of Indian ETFs and Index Funds which track the same benchmark. Four different index funds along with four different exchange traded funds are considered in the study respectively tracking same benchmark. The study is based on secondary data and covers a period of five years i.e. from 2012-16 for the purpose of evaluating relative performance of selected ETFs and Index Funds. The parameters used for evaluating the performance are: Return, Risk, Sharpe Ratio, Beta, Jensen's Alpha and R square. This study will enable to recognize the difference in performance of two significant similar passive investment strategies.
\end{abstract}

Keywords: ETF s, Index funds, Performance, NAV, Return, Risk

\section{INTRODUCTION}

Exchange traded funds and Index funds are notew orthy examples of financial innovation. Goal of both the funds is essentially the same, i.e. to provide investors with a way to own a well-diversified indexed portfolio by using economies of scale to buy large quantities of stock at low cost. A $n$ index fund is a type of mutual fund with a portfolio constructed to match or track the components of a market index .It is a passive form of investment which has been successful in outperforming most actively managed mutual funds. Similarly, ETFs imply a basket of securities that is designed to track a benchmark. They mimic indices, gold or a basket of commodities. B oth Index funds and ETFs track benchmarks but they differ in various aspects. Index funds can be traded only at the end of the day at their Net Asset value whereas ETFs have provided investors with the twin feature of a stock and mutual fund as it can traded at any time of trading day just like stocks. Its unique creation and redemption process provides an in-built arbitrage mechanism that prevents significant price deviations between market value of ETF and $\mathrm{Net}$ A sset $V$ alue of underlying asset. ETFs generally have lower expense ratio then mutual funds. In addition to this ETFs also enable investors to save tax by delaying capital gain up to the end to pay for redemption.

The history of mutual funds dates back to almost 200 years when first mutual fund was introduced in B elgium in 1822. The advent of the mutual funds in U.S is market by the starting of the Massachusetts Investors' Trust in Boston, Massachusetts, in 1924. However in India inception of mutual funds goes back to 1963 when U nit Trust of India was launched. From 1998 to 2008, mutual fund industry grew by nearly 22 percent CA GR. Investors in India are now very much aware about the mutual funds but Index fund industry is quiet new to them as first open ended index fund scheme was introduced in 2010 by $\mathrm{ICICl}$ prudential A sset $\mathrm{M}$ anagement Company.

On the other hand ,Exchange traded funds are not as old as mutual funds they were originated in 1993 by State Street Global Advisors, when the Standard \& 
Poor's Depository Receipts (SPDRs) were introduced. It tried to replicate the performance of S\&P 500 Index. Morgan Stanley started the second ETF with the introduction of World Equity Benchmark Shares (WEBS).A fter the initial success of ETFs, brokerage firms and stock exchanges have launched a number of ETFs tracking different indices. By the late nineties there were 30 US ETFS representing $\$ 33$ billion net asset value. Whereas, ETFs were introduced in India in 2001 with the launch of Nifty Benchmark Exchange Traded Scheme meant to track $S \& P$ CNX Nifty which allowed investors to obtain diversified portfolio with one single decision. Even after a decade i.e. in A pril 2010 there were only 19 ETFs traded in the Indian market with the trading volume of Rs.505 crore .Within a year that is by October 2011 number of ETFs substantially increased to 30 with the trading volume of Rs. 1962 crore and as on December 2015 there were 53 ETFs trading in the market with the trading value of Rs. 2116.84 crore.

ETFs and Index funds have been in existence in existence in for more than a decade now but has not gained the kind of popularity that conventional mutual funds enjoy. Limited investors are aware about the concept of Index Fund and Exchange Traded Funds. Relatively little is known about the extent of tracking error experienced by them. Thus, in this study efforts have been made to investigate the performance of ETFs and Index Funds that track similar indices as it would enable us to know the difference in performance of two very similar passive investment strategies. Study will further add to the literature available.

\section{LITERATURE REVIEW}

K ostovetsky (2003) compared ETFs and index funds, demonstrating that they differ because of management expenses, transaction fees and tax efficiency. A uthor suggested that comparing tracking error of ETFs and index funds is difficult because of the lack of a true benchmark for comparison. Further, it was recommended to use a multi period model instead of one-period model as it will enable to overcome the problems faced in one-period model being used in the study.

J .Gayathri and P.Bhuvaneswari (2009) compared the risk and return of ETFs with their index using Sharpe ratio and Treynor's ratio. Evaluation was done for the period of three years i.e. from 2005 to 2007. This study revealed that general NIFTY BEES delivered enhanced returns than other option based funds like Junior BEES, Liquid BEES and Bank $B E E S$ during the period of study.

A. Agapova (2011) examined the effects of substitutability of two similar investment vehicles i.e. conventional index mutual funds and exchangetraded funds. A uthor attempted to elucidate the cooccurrence of these vehicle types, which have distinctly different organizational structures but offer a right on the same underlying index return process. This study compared aggregate fund flows into conventional open-ended index funds to those into ETFs for various underlying indexes. The study revealed that conventional funds and ETFs are not perfect substitutes for one another.

Prashanta Athma and Raj Kumar (2011) attempted to evaluate the performance of ETFs and Index Funds in India. The study was based on secondary data and covering period of five years i.e. from 2005 to 2009.N et A sset Value, Risk, Return, Expenses Ratio, Tracking Error, Reward to $V$ ariability and Differential Return were used as a measure to evaluate performance. The statistical tools like Standard Deviation, B eta, Alpha, R-squared and Sharpe Ratio were used for data analysis. A fter data analysis it was established that ETFs have given better opportunity for the small investors in terms of diversified portfolio with a small amount of money, low expense ratio, reduced tracking error, lower risk and volatility as compared to Index Funds. Thus, concluding that ETFs are a better form of investment when compared with index funds.

Swati Garg and Y. P. Singh (2013) compared the performance of ETFs and Index Funds. Five ETFs and Index Funds tracking the same benchmark indices has been analyzed in this study over a period of three years ranging from J une 2006 to December 2009. The analysis exhibits that over long term investment horizon ETFs perform better in terms of their replication strategy, tracking ability and performance effectiveness. However, it was evident from the study that short term investors face disadvantage from investing in ETFs.

S.Narend (2014) examined the performance of exchange traded funds and index funds using tracking error, active returns and Jensen's alpha from the period of their inception up to July 2013. The analysis revealed that that tracking error was higher for ETFs when compared to index mutual funds. It was also discovered that both index fund and ETFs have not been able to provide excess returns over the market. In comparison to ETFs, index funds have outperformed in terms of tracking error and Jensen's 
alpha whereas in terms active return ETFs have performed better.

Gerasimos G. Rompotis (2015) examined the return, risk and expense features of ETFs and mutual funds present in Greek Stock Market. Under this study ALPHA ETF FTSE ATHEX 20 and four different open ended mutual funds, each of which has the same benchmark as the ETF are considered. It was found that classic mutual funds are more expensive than the ETF but they perform better and are less volatile. Additionally, the performance of the ETF in respect of the return of the tracking index is found to be better than the corresponding performance of the funds. Through the study, it was evident that tracking error of the ETF is reasonably lower than the actively managed funds but greater than that of the index fund.

P.M ishra and G.Singh(2016) attempted to make an intra-class performance evaluation of some Indian index funds. Graphical interpretations were used along with statistical tools like R-square and tracking error values. T wo models of tracking error have been employed to test empirically the performance of the selected index funds. Empirical results revealed that out of selected index funds, SBI Nifty Index fund outperformed the other six index funds during the period under study. SBI Nifty Index fund was also able to limit the tracking error to an acceptable limit.

\section{OBJECTIVE OF THE STUDY}

This study aims to comparatively evaluate the performance of selected exchange traded funds and index funds on the basis of annual returns for the period of five years i.e. from 2012-2016.

\section{DATA AND METHODOLOGY}

Number of ETFs being traded on Indian Stock exchange has increased significantly. As on December 2015 there were 53 ETFs trading in the market with the trading value of Rs. 2116.84 crore and now as per Bloomberg Intelligence Report "India's exchange traded funds (ETF) market is the second fastest growing market, second only to Japan, with assets more than doubling to $\$ 4$ billion from $\$ 1.9$ billion in the past three years". Along with ETFs, market of index funds is also expanding at a greater pace. However, for the purpose of present study it was not feasible to cover the entire market, thus only four ETFs and four Index funds tracking NIFTY 50 were considered. Selection of funds was based on average asset under management and Crisil ranking. The study covers a period of five years from 2012 to 2016 for the purpose of evaluating the performance of selected Index Funds and Exchange Traded Funds in India. Data used is entirely secondary and is extracted from Association of Mutual Funds in India (AMFI) reports, articles, newspapers, and websites of various asset management companies. Parameters used for evaluating the performance are A nnual Returns, Risk, Sharpe Ratio, B eta, A Ipha and R square.

\section{RETURNS OF ETFS AND INDEX FUNDS IN INDIA}

ETFs have been widely gaining attraction of investors as they provide the twin feature of stock and mutual funds. They provide investors with broad exposure to the stock markets in different countries and specific sectors, with relative ease, on a real-time basis that too at a low cost.

Table below gives details relating to the annual returns of the ETFs and Index Funds during the period 2012 to 2016.

Table 1: Annual Returns of Index Funds (Figures in \% )

\begin{tabular}{|c|c|c|c|c|c|c|}
\hline S.No. & Name of the Fund & 2012 & 2013 & 2014 & 2015 \\
\hline 1 & $\begin{array}{c}\text { Franklin India Index } \\
\text { Nifty Plan }\end{array}$ & 27.65 & 6.87 & 31.17 & -3.58 \\
\hline 2 & $\begin{array}{c}\text { HDFC Index Fund } \\
\text { Nifty Plan }\end{array}$ & 27.59 & 7.44 & 32.18 & -3.09 \\
\hline 3 & $\begin{array}{c}\text { IDBI Nifty Index } \\
\text { Funds }\end{array}$ & 27.71 & 7.16 & 30.80 & -4.44 & 2.37 \\
\hline
\end{tabular}




\begin{tabular}{|c|c|c|c|c|c|c|}
\hline 4 & $\begin{array}{c}\text { UTI Nifty Index } \\
\text { Funds }\end{array}$ & 28.32 & 6.86 & 31.77 & -3.35 & 4.00 \\
\hline
\end{tabular}

Source: Value Research

As per Table 1, Annual return of all the four Index Fund reveals that in 2012 UTI Nifty Index Funds provided highest return of $28.32 \%$.W hereas, HDFC Index Fund Nifty Plan has outperformed in the year 2013 and 2014.In the year 2015 it was observed that index funds have performed negatively even then performance of HDFC Index Fund Nifty Plan is better than other

index funds as it provided least negative returns. In the year 2016 again UTI Nifty Index Fund has managed to outperform all other selected index funds.

Table 2: Annual Returns of Exchange Traded Funds (Figures in \%)

\begin{tabular}{|c|c|c|c|c|c|c|}
\hline S.No. & Name of the Fund & 2012 & 2013 & 2014 & 2015 & 2016 \\
\hline 1 & Kotak Nifty ETF & 29.16 & 7.91 & 31.22 & -2.91 & 2.89 \\
\hline 2 & $\begin{array}{c}\text { Aditya Birla Sun Life } \\
\text { ETF }\end{array}$ & 28.81 & 7.78 & 31.89 & -2.54 & 4.63 \\
\hline 3 & $\begin{array}{c}\text { ICICI Prudential } \\
\text { Nifty iWIN ETF }\end{array}$ & - & - & 32.36 & -2.96 & 4.39 \\
\hline 4 & $\begin{array}{c}\text { Reliance ETF Nifty } \\
\text { BeES }\end{array}$ & 29.34 & 6.62 & 31.22 & -3.20 & 3.92 \\
\hline
\end{tabular}

Source: Value Research

As per Table 2, In 2012 Reliance Nifty BeES provided highest return of $29.34 \%$.W hereas, K otak Nifty ETF has outperformed other funds in the year 2013. Return for ICICI Prudential Nifty iWIN ETF was not available as it was launched in march 2013 although in 2014 just after its inception it managed to outperform other funds whereas in subsequent years A ditya B irla Sun Life ETF provided better returns.

Through, Comparative analysis it was observed that, all the 8 funds are tracking Nifty 50 but still are providing different returns. In all the five years ETFs have provided highest return. In 2012, Reliance NIFTY ETF BeES provided the highest return of 29.34\%.In 2013, Kotak Nifty ETF provided highest return of $7.91 \%$.In 2014,ICICI Prudential iW IN Nifty ETF provided with highest return of $32.36 \%$ even in 2015 which was seen an year of negative returns ETFs performed better than Index Funds as lowest negative return was provided by an ETF .Then in 2016 when market was recovering, ETFs recovered at a greater pace than Index Funds and A ditya Birla Sun Life ETF provided highest return out of selected funds.

In totality it was observed that although Index Funds and ETFs are tracking same index but still ETFs are performing better than Index funds.

\section{RISK ANALYSIS OF ETFS AND INDEX FUNDS}

Despite of looking at returns investors must evaluate the risk involved before investing. There are number of ratios which investors should consider before making their investments. Risk can be analyzed with the help of Standard Deviation, Sharpe Ratio, Beta, A Ipha and R-squared.

Tables below provide the details relating to Standard deviation, Sharpe ratio, B eta, Alpha and R-squared value relating to selected index funds and exchange traded funds. 
Table 3: R isk analysis of Index F unds (as on $31^{\text {st }}$ Oct 2017)

\begin{tabular}{|c|c|c|c|c|c|c|}
\hline S.No. & $\begin{array}{c}\text { Name of the } \\
\text { Fund }\end{array}$ & $\begin{array}{c}\text { Standard } \\
\text { Deviation (\%) }\end{array}$ & $\begin{array}{c}\text { Sharpe Ratio } \\
(\%)\end{array}$ & Alpha (\%) & Beta (\%) & R Square \\
\hline 1 & $\begin{array}{c}\text { Franklin India } \\
\text { Index Nifty Plan }\end{array}$ & 13.50 & 0.29 & 0.18 & 0.99 & 1.00 \\
\hline 2 & $\begin{array}{c}\text { HDFC Index Fund } \\
\text { Nifty Plan }\end{array}$ & 13.51 & 0.33 & 0.82 & 0.99 & 1.00 \\
\hline 3 & $\begin{array}{c}\text { IDBI Nifty Index } \\
\text { Fund }\end{array}$ & 13.55 & 0.22 & 0.36 & 1.00 & 1.00 \\
\hline 4 & $\begin{array}{c}\text { UTI Nifty Index } \\
\text { Fund }\end{array}$ & 13.48 & 0.33 & 0.84 & 0.99 & 1.00 \\
\hline
\end{tabular}

Source: Value R esearch

Table 4: Risk Analysis of Exchange Traded Funds (as on $31^{\text {st }} 0$ ct 2017)

\begin{tabular}{|c|c|c|c|c|c|c|}
\hline S.No. & Name of the Fund & $\begin{array}{c}\text { Standard } \\
\text { Deviation (\%) }\end{array}$ & $\begin{array}{c}\text { Sharpe Ratio } \\
(\%)\end{array}$ & Alpha (\%) & Beta (\%) & R Square \\
\hline 1 & Kotak NIFTY ETF & 13.46 & 0.30 & 0.36 & 0.99 & 0.99 \\
\hline 2 & $\begin{array}{c}\text { Aditya Birla Sun Life } \\
\text { ETF }\end{array}$ & 13.37 & 0.37 & 1.29 & 0.98 & 1.00 \\
\hline 3 & $\begin{array}{c}\text { ICICl Prudential } \\
\text { Nifty IWIN ETF }\end{array}$ & 13.54 & 0.36 & 1.17 & 1.00 & 1.00 \\
\hline 4 & $\begin{array}{c}\text { Reliance Equity } \\
\text { Nifty BeES }\end{array}$ & 13.62 & 0.34 & 0.92 & 1.00 & 1.00 \\
\hline
\end{tabular}

Source: Value Research

N ote: The Risk M easures have been calculated using calendar month returns for the last three years.

\section{Standard Deviation}

Standard deviation is an especially useful tool in investing and trading strategies, as it helps measure market and security volatility. It is found that among the ETFs, Reliance ETF Nifty BeES is having the highest risk i.e. $13.62 \%$ whereas in case of Index Funds, IDBI Nifty Index Fund has highest risk of $13.55 \%$. The standard deviations of the ETFs are higher than the Index Funds. It means that the deviation of expected return is more in ETFs than Index Funds. ETFs are riskier compared to Index
Funds as a result, its returns are higher as compared to Index Funds as seen earlier.

\section{Sharpe R atio}

Sharpe ratio shows the ratio of reward to variability. Higher the ratio, better performance, in terms of the return for the risk taken. It is found that all the ETFs and Index Funds are showing a positive Sharpe ratio. When compared to Index Funds, ETFs have the higher ratio. According to Sharpe ratio, ETFs are 
giving better performance for extra risk taken by the investors.

\section{Alpha}

The higher the alpha, more the portfolio is able to earn above the predicted level. In the ETFs and Index Funds Reliance Nifty BeES is giving highest alpha which means this index fund is able to perform much above the predicted level. Overall, ETFs have higher al pha values than index funds.

\section{Beta Value}

B eta measures the systematic risk and explains the nature of the volatility of the security return with that of the market return. If beta values are less than one, it means that funds risk is less than the market risk; if it is one, it means the funds risk is same as that of the market risk and if the beta is more than one, the risk of the funds is greater than that of the market. All the funds, by and large, have the beta values on an average approximately equal to 0.99 , implying lower volatility in the returns of the ETFs and Index Funds than the underlying Index volatility. Risk of ETFs as well as Index Funds is found to be less than market risk.

\section{R-Squared Value}

All the ETFs and Index funds have the R-squared values as 1.00 except K otak Nifty ETF. It means that, they have exact correlation with the underlying Index and are moving in the same direction as that of the market returns and as far K otak Nifty is concerned it is unable to exactly track the underlying benchmark.

\section{CONCLUSION}

In this study eight funds were selected that tracked Nifty 50 for which risk and return was analyzed on the basis of data extracted from secondary sources. A nalysis revealed that in terms of annual returns ETFs provided highest return in all the five years, even when market was falling ETFs managed to perform better than Index Funds. Further, risk was analyzed using standard deviation, Sharpe ratio, B eta, Alpha and $R$ squared values. Through analysis it was discovered that ETFs are more risky than Index Funds thus are generating better returns. Value of alpha for all the eight fund is positive which is a noteworthy point as it shows that all the funds are generating excess return over market return. Beta value shows a lower volatility among funds. Further, the value of $r$ square for approximately all the funds is either 0.99 or 1 which illustrates that funds are moving in same direction as of underlying index.

\section{LIMITATIONS}

The major limitation of this study is that the sample size was reduced considerably. The results of this study could vary if the size of sample is increased. Thus there is a great scope for further study.

\section{REFERENCES}

1) Agapova, A. (2011). Conventional mutual index funds versus exchange-traded funds. J ournal of Financial Markets, 14(2), 323343.

2) A thma, P., \& K umar, K. R. (2011). ETF visà-vis index funds: $A n$ evaluation. Asia Pacific Journal of Research in Business M anagement, 2(1), 188-205.

3) J.Gayathri and P.Bhuvaneshwari, (2009).Performance Analysis of Exchange Traded Funds in India; Smart J ournal of Business Management Studies, 5(1), Jan-J un 2009.

4) K ostovetsky, Leonard, (2003), Index M utual Funds and Exchange Traded Funds', J ournal of Portfolio Management, 29 (4), pp.80-92.

5) M ishra, P., \& Singh, G. (2016). Performance Evaluation of Some Index Funds-Indian Perspective. Acta Universitatis Danubius. E conomica, 12(2).

6) Narend, S. (2014). Performance of ETFs and Index Funds: a comparative analysis (Doctoral dissertation, Doctoral dissertation, Indian Institute of Technology, Madras). A vailable At: https://nseindia.com/research/content/RP_15 M Mar2014 .pdf

7) Rompotis, G. (2015). ETFS vs. mutual funds: evidence of the Greek market. SouthEastern Europe J ournal of Economics, 9(1).

8) Swati Garg \& Dr. Y. P. Singh. (2013).An Empirical Comparison of ETFs and Index Funds Performance In India, International J ournal of Applied Financial Management Perspectives (c) P ezzottaite J ournals,2 (3).

\section{ONLINE SOURCES}

1) http://www.amfiindia.com

2) http://www.nseindia.com

3) https://www.valueresearchonline.com 